\title{
Photoinhibition and loss of photosystem II reaction centre proteins during senescence of soybean leaves. E nhancement of photoinhibition by the 'stay-green' mutation cytG
}

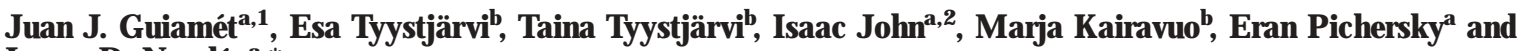 \\ L arry D. N oodén ${ }^{\mathrm{a}, *}$ \\ ${ }^{a}$ D epartment of Biology, U niversity of M ichigan, Ann A rbor, M I 48109-1048, U SA \\ ${ }^{b}$ D epartment of Biology, U niversity of Turku, BioC ity A, FIN-20014 T urku, Finland \\ 1P resent address: Instituto de Fisiología V egetal, U niversidad Nacional de La Plata, c.c.327 1900-L a Plata, Argentina \\ 2P resent address: School of Biological Sciences, U niversity of Exeter, Exeter EX 4 4PS, U nited Kingdom \\ *Corresponding author, e-mail: Idnum@umich.edu
}

Received 7 M ay 2001; revised 7 J anuary 2002

The 'stay-green' mutation cytG in soybean (G lycine max) partially inhibits the degradation of the light-harvesting complex II (L H C II) and the associated chlorophyll during monocarpic senescence. cytG did not alter the breakdown of the cytochrome b6/f complex, thylakoid AT P synthase or components of Photosystem I. In contrast, cytG accelerated the loss of oxygen evolution activity and PSII reaction-centre proteins. These data suggest that L H CII and other thylakoid components are degraded by separate pathways. In leaves induced to senesce by darkness, cytG inhibited the breakdown of LHCII and chlorophyll, but it did not enhance the loss of PSII-core components, indicating that the accelerated degra- dation of PSII reaction centre proteins in cytG was light dependent. Illumination of mature and senescent leaves of wildtype soybean in the presence of an inhibitor (lincomycin) of chloroplast protein synthesis revealed that senescence per se did not affect the rate of photoinhibition in leaves. L ikewise, mature leaves of the cytG mutant did not show more photoinhibition than wild-type leaves. H owever, in senescent cytG leaves, photoinhibition proceeded more rapidly than in the wild-type. We conclude that the cytG mutation enhances photoinhibition in senescing leaves, and photoinhibition causes the rapid loss of PSII reaction-centre proteins during senescence in cytG.

\section{Introduction}

The breakdown of thylakoid membranes and stromal proteins of the chloroplasts during senescence causes the photosynthetic activity of senescing leaves to decline to very low levels (G epstein 1988, N oodén 1988). The dismantling of thylakoid membranes is characterized by chlorophyll (Chl) degradation and loss of photosynthetic electron transport activity (Holloway et al. 1983, $G$ epstein 1988). I nitially, the decline in photosynthetic electron transport during senescence is due to the loss of the cyt b6/f complex, which is followed by a decrease in Photosystem I (PSI) and Photosystem II (PSII) activ- ities and, later, ATP synthase (Holloway et al. 1983, $\mathrm{G}$ epstein 1988). The decrease in the activity of the photosynthetic light reactions in the thylakoids correlates with the degradation of the protein components of each complex, but the mechanism and regulation of thylakoid protein catabolism are poorly understood.

The decline of photosystem activity during senescence may be caused in part by photodamage. Susceptibility to photodamage increases in excised rye leaves during low-light-induced senescence ( $\mathrm{K}$ ar et al. 1993). Photoprotective mechanisms might decline during sen-

A bbreviations - Chl, chlorophyll; CP26, 26 kDa Chl a/b-binding protein; CP29, 29 kDa Chl a/b-binding protein; CP47, 47 kD a Chl a-binding protein; cyt b6/f, cytochrome b6/f complex; cyt $f$, cytochrome f; cytG, a maternally inherited stay-green mutant of soybean; DA F, days after flowering: DCBO, 2,6-dichloro-p-benzoquinone; DCM U, 3-(3,4,-dichlorophenyl)-1,1,-dimethylurea; $\mathrm{F}_{\mathrm{v}} / \mathrm{F}_{\mathrm{M}}$, ratio of variable to maximum $\mathrm{Chl}$ a fluorescence in darkadapted leaves; HEPES, (N [2-hydroxyethyl]piperazine-N '-[2-ethanesolfonic acid]); L HCI, light-harvesting complex associated with PSI; L HCII, lightharvesting complex associated with PSII; PSI and PSII, photosystems I and II, respectively; PPFD, photosynthetic photon flux density; $q_{N}$, nonphotochemical quenching, $\mathrm{q}_{\mathrm{p}}$, photochemical quenching; TM BZ, tetramethyl benzidine. 
escence, since senescent leaves may contain lower levels of zeaxanthin and other xanthophyll cycle carotenoids (A fitlhile et al. 1993). Senescencerelated changes in leaf orientation of the flag leaf in rice may also increase light exposure at midday, thereby accelerating photoinhibition under field conditions (M urchie et al. 1999). These connections between senescence and photodamage prompted us to study the susceptibility of senescing leaves to photoinhibition of PSII.

Several mutations interfere with $\mathrm{Chl}$ degradation and cause the retention of $\mathrm{Chl}$ in senescent leaves of various species (Thomas and Smart 1993, B achmann et al. 1994, N oodén and Guiamét 1996). Chl retention in these 'staygreen' mutants correlates with the preservation of $\mathrm{Chl}$ binding proteins and certain other protein components of the thylakoid membranes. In soybean, the maternally inherited mutation cytG (Bernard and Weiss 1973) blocks the degradation of the light-harvesting complex of PSII and its associated pigments (G uiamét et al. 1991, Chao et al. 1995). cytG appears to act on Chl degradation rather than synthesis (Canfield et al. 1995) suggesting that at least one non-nuclear gene is involved in thylakoid membrane disassembly during senescence. The retention of excess $\mathrm{LHCll}$ in senescent leaves of cytG may increase the effective size of light-harvesting antenna in PSII with no concomitant increase in light energy utilization for $\mathrm{CO}_{2}$ fixation in the mutant ( $\mathrm{G}$ uiamét et al. 1990). This might favour photodamage of PSII reaction centres in senescent leaves of the mutant.

The main objective of this work was to determine if photodamage increases during senescence of soybean leaves, and if there are differences in rate of photoinhibition between wild-type and cytG leaves. A dditionally, we report on the effects of cytG on the degradation of thylakoid proteins besides L HCII in senescing leaves. In this process, we have also characterized the normal breakdown of the photosynthetic apparatus.

\section{M aterials and methods}

\section{Plant material and growing conditions}

Soybean (Glycine max [L.] M err.) seeds of wild-type cv. Clark, and a near-isogenic line carrying the maternally inherited mutation cytG were obtained from $\mathrm{Dr} R$. Bernard, Department of A gronomy, U niversity of IIlinois, USA. Soybeans were cultured as described previously (Guiamét et al. 1990) in pots with soil, watered daily and fertilized regularly with N-P-K (20:20:20, w/ $w / w)$. Plants were initially grown under long days ( $16 \mathrm{~h}$, $350 \mu \mathrm{mol} \mathrm{m} \mathrm{m}^{-2} \mathrm{~s}^{-1}$ of photosynthetically active radiation) at $27 / 21^{\circ} \mathrm{C}$ day/night temperature. After 2-3 weeks (unifoliate leaves fully expanded), they were shifted to short days $\left(10 \mathrm{~h}, 27 / 21^{\circ} \mathrm{C}\right.$ day/night temperature) for the duration of the experiment.

In some experiments, leaf senescence was induced by darkness. These plants were grown under long days for 3 weeks until the unifoliate leaves were completely expanded and then transferred to continuous darkness at $25^{\circ} \mathrm{C}$. Thereafter, all manipulations (e.g. watering, sampling) were performed under a $\operatorname{dim}\left(<1 \mu \mathrm{mol} \mathrm{m} \mathrm{m}^{-2} \mathrm{~s}^{-1}\right)$ green safelight.

\section{Sampling}

For studies with plants undergoing monocarpic senescence, samples of the uppermost fully expanded leaf at flowering were taken at different stages of development, from leaf maturity to abscission. M easurements involving dark-induced senescence were performed on the unifoliate leaves. Since there were small differences in the timing of the degradation of thylakoid proteins between different batches of soybeans, we have indicated the changes in $\mathrm{Chl}$ content in wild-type for each particular experiment shown.

\section{Thylakoid isolation}

Thylakoids from mature and senescent leaves of both wild-type leaves (cv. Clark) and from cytG leaves were isolated using a method modified from Camm and G reen (1980). L eaves were harvested and homogenized in chilled buffer (50 mM HEPES, pH 7.5, $0.4 \mathrm{M}$ sucrose, $2 \mathrm{mM} \mathrm{MgCl} 2,1 \mathrm{mM}$ EDTA, $0.2 \% \mathrm{w} / \mathrm{v}$ bovine serum albumin) with a Waring blender. The homogenate was filtered through 4 layers of cheesecloth and a $10-\mu \mathrm{m}$ pore nylon mesh, and centrifuged at $3000 \mathrm{~g}$ for $5 \mathrm{~min}$ at $4^{\circ} \mathrm{C}$. The resultant pellet was resuspended in wash buffer (50 $\mathrm{mM}$ HEPES, pH 7.5, $10 \mathrm{mM} \mathrm{NaCl}$ ) and centrifuged again as above. This second pellet was resuspended in a small volume of wash buffer containing glycerol $(10 \% \mathrm{v} /$ v) and stored at $-70^{\circ} \mathrm{C}$ until further analysis. For measurements of senescence-induced changes in photosystem II activity, thylakoids were prepared essentially as described above, except that the homogenization buffer contained $0.4 \mathrm{M} \mathrm{N} \mathrm{aCl}$ instead of sucrose, the wash buffer was $50 \mathrm{mM}$ HEPES, pH 7.5, $0.25 \mathrm{M} \mathrm{NaCl}, 5 \mathrm{mM}$ $\mathrm{M} \mathrm{gCl}_{2}$, and thylakoids were resuspended and frozen in $50 \mathrm{mM}$ HEPES, pH 7.5, $0.4 \mathrm{M}$ sucrose, $15 \mathrm{mM} \mathrm{NaCl}$ and $0.2 \% \mathrm{w} / \mathrm{v}$ bovine serum albumin. For photoinhibition experiments, thylakoids were isolated according to Pätsikkä et al. (1998).

\section{Photoinhibition experiments}

For in vivo photoinhibition measurements, mature and senescing leaves of wild-type cv. Clark and cytG were incubated overnight under very dim light with their petioles immersed in a solution of lincomycin $\left(\mathrm{g} \mathrm{I}^{-1}\right)$. The leaves were then illuminated at a PPFD of $560 \pm 40$ $\mu \mathrm{mol} \mathrm{m} \mathrm{m}^{-2} \mathrm{~s}^{-1}$ at $30^{\circ} \mathrm{C}$. A fter 0,2 and $4 \mathrm{~h}$ of illumination, thylakoids were isolated and oxygen evolution activity was measured immediately. The rate constant of photoinhibition was calculated from first-order fits (Tyystjärvi and A ro 1996) of the loss of oxygen evolution activity. A $n$ aliquot of each thylakoid sample was used for determination of the $D 1$ protein content by Western blotting.

In vitro photoinhibition was measured in thylakoids 
isolated from both attached, normally senescing leaves at 20, 45 and $55 \mathrm{DAF}$, and from detached, dark-senescent leaves. To obtain the dark senescent material for in vitro photoinhibition, leaves of cv. Clark and cytG were allowed to senesce in darkness for 15 days until the $\mathrm{Chl}$ concentration of the wild-type leaves dropped to $26 \%$ and that of cytG to $49 \%$ of the initial value. Thylakoids isolated from control and senescent leaves were suspended in $50 \mathrm{mM}$ HEPES (pH 7.6), $0.3 \mathrm{M}$ sorbitol, $20 \mathrm{mM} \mathrm{N} \mathrm{aCl}$ and $5 \mathrm{mM} \mathrm{M} \mathrm{gCl}$ at a Chl concentration of $50 \mu \mathrm{g} \mathrm{ml}^{-1}$ and illuminated at $20^{\circ} \mathrm{C}$ with a heat-filtered $250 \mathrm{~W}$ projector lamp delivering $1000 \mu \mathrm{mol} \mathrm{m} \mathrm{m}^{-2} \mathrm{~s}^{-1}$ of photosynthetically active radiation at the level of the thylakoid suspension. A liquots of thylakoids were taken at regular intervals for PSII activity measurements as described below.

\section{Protein electrophoresis}

For SD S-PAGE, thylakoids were solubilized with Laemmli's solubilization buffer (L aemmli 1970). Each well was loaded either on the basis of $\mathrm{Chl}$ content or leaf area, as indicated in each figure. Proteins were separated in either $13 \%(\mathrm{w} / \mathrm{v})$ or $11-16 \%(\mathrm{w} / \mathrm{v})$ acrylamide concentration gradient gels.

\section{Western blot analysis}

Proteins separated by SDS-PAGE were electro-transferred to nitrocellulose membranes at $70 \mathrm{~V}$ for $3 \mathrm{~h}$, or at $200 \mathrm{~mA}$ overnight, in a buffer containing $48 \mathrm{mM}$ Tris, $39 \mathrm{mM}$ glycine, $0.037 \% \mathrm{w} / \mathrm{v}$ SD S and $20 \%$ v/v methanol. $\mathrm{N}$ itrocellulose membranes were blocked, incubated with antibodies and developed as described earlier (G uiamét and Giannibelli 1996) or with a chemiluminescent detection system based on horseradish peroxidase.

\section{$\mathrm{H}$ eme peroxidase staining of cytochrome $\mathrm{f}$}

$M$ ildly denaturing electrophoresis was performed as described by Camm and Green (1989). Cytochrome $f$ was detected in mildly denaturing gels by staining for the peroxidase activity of its heme group as described in Thomas et al. (1976). A fter soaking the gels for $2 \mathrm{~h}$ in a solution of $1.9 \mathrm{mM}$ tetramethyl benzidine (TM BZ) in $30 \%(\mathrm{v} / \mathrm{v})$ methanol, $175 \mathrm{mM} \mathrm{N}$ a-acetate buffer $(\mathrm{pH}$ 5), the reaction was initiated by adding hydrogen peroxide to a final concentration of $30 \mathrm{mM}$. Band intensity was quantified by laser densitometry at $600 \mathrm{~nm}$. Since staining intensity was linear for loads between 5 and $15 \mu \mathrm{g}$ $\mathrm{Chl}$ and up to $15 \mathrm{~min}$ of incubation, gels were routinely loaded with 7.5-10 $\mu \mathrm{g}$ of $\mathrm{Chl}$ and developed for $15 \mathrm{~min}$. All operations were performed in darkness or under subdued light.

\section{N orthern blot analysis}

Leaves were harvested at midday and RNA was extracted as in John et al. (1995). R N A was electrophor- esed in denaturing gels containing formaldehyde under standard conditions (Sambrook et al. 1989) and transferred overnight to nylon membranes ( $G$ ene Screen, D u Pont, USA) by capillary transfer. Blots were UV crosslinked at $1200 \mathrm{~J}$. Blotted R N A was prehybridized at $42^{\circ} \mathrm{C}$ for $4 \mathrm{~h}$ in formamide $(50 \% \mathrm{v} / \mathrm{v})$, SD S $(1 \% \mathrm{v} / \mathrm{v})$, $1 \mathrm{M} \mathrm{NaCl}$, dextran sulphate $(10 \% \mathrm{w} / \mathrm{v})$ and denatured salmon sperm DNA $\left(0.1 \mathrm{mg} \mathrm{ml}^{-1}\right)$. Radiolabelled probes were added to this solution and hybridized overnight at $42^{\circ} \mathrm{C}$. M embranes were washed twice for $5 \mathrm{~min}$ each with $2 \times$ SSC $(1 \times$ SSC is $0.15 \mathrm{M} \mathrm{NaCl}, 0.15 \mathrm{M}$ sodium citrate, $\mathrm{pH} 7.0)$ plus SDS $(0.1 \% \mathrm{w} / \mathrm{v})$ and twice for $15 \mathrm{~min}$ each with $0.1 \times$ SSC plus SD S $(0.1 \% \mathrm{w} / \mathrm{v})$.

Plasmids containing the soybean $18 \mathrm{~S}$ rR N A gene and the barley psbA gene were digested with $\mathrm{E} C \mathrm{R} \mathrm{R} / \mathrm{B}$ amH I (18S rR N A) and E coRI/H incll (psbA), and the inserts were radiolabelled with a random primed labelling kit (Boehringer $M$ annheim) following the manufacturer's instructions. Blots were hybridized first with the psbA probe, then the probe was stripped and the same blot was hybridized with the soybean 18S rRNA probe. L evels of the psbA and 18S rRNA mRNAs were quantified with a Bio-R ad M olecular I mager System using a BI Imager Screen (Bio-R ad L aboratories, H ercules, CA, USA).

\section{1 synthesis in vivo}

Eight leaf disks (12-mm diameter) were incubated for 1 $\mathrm{h}$ at $560 \pm 40 \mu \mathrm{mol} \mathrm{m}-2 \mathrm{~s}^{-1}$ and $30^{\circ} \mathrm{C}$ in $4 \mathrm{ml}$ of distilled water containing $0.37 \mathrm{M} \mathrm{Bq}$ of ${ }^{35} \mathrm{~S}$-methionine (37.0 $\left.\mathrm{M} \mathrm{Bq} \mu \mathrm{mol}^{-1}\right)$. A fter this feeding period, thylakoids were isolated, polypeptides were solubilized with Laemmli's solubilization buffer (L aemmli 1970), separated by SD SPAGE, and transferred to a nitrocellulose membrane as described above, and autoradiograms were developed using Kodak X-OM AT AR film (SIG M A Chemical Co., St. Louis, M O, USA).

\section{P hotosystem II activity}

For photoinhibition experiments, light-saturated oxygen-evolution activity of PSII was measured polarographically from isolated thylakoids as described in Pätsikkä et al. (1998). 2,6-dichloro-p-benzoquinone was used as electron acceptor. Changes in PSII activity during senescence were measured according to $\mathrm{K}$ im et al. (1994).

\section{Chlorophyll a fluorescence measurements}

The ratio of variable to maximum $\mathrm{Chl}$ a fluorescence $\left(\mathrm{F}_{\mathrm{v}} / \mathrm{F}_{\mathrm{M}}\right)$, and the photochemical $\left(\mathrm{q}_{\mathrm{p}}\right)$ and non-photochemical $\left(q_{N}\right)$ components of fluorescence quenching were measured in attached leaves with an OS-500 M odulated Fluorometer (O pti-Sciences Inc., Tyngsboro, M A, USA). L eaves were dark adapted for $15 \mathrm{~min}$ before measuring $\mathrm{F}_{0}$ (fluorescence with all PSII centres open) and $\mathrm{F}_{\mathrm{M}}$ (fluorescence under a saturating flash of light). 
For the analysis of the quenching parameters, leaves were illuminated continuously with an actinic light source $\left(350 \mu \mathrm{mol} \mathrm{m} \mathrm{m}^{-2} \mathrm{~s}^{-1}\right)$, and saturating flashes of light ( $10 \mathrm{mmol} \mathrm{m}^{2} \mathrm{~s}^{-1}$, duration $0.8 \mathrm{~s}$ ) were given every $20 \mathrm{~s}$. A the end of each run, the quenched $F_{0}$ level $\left(F_{\text {od }}\right)$ was measured with the actinic light off and illuminating the leaf with a far-red source. The coefficients $q_{P}$ and $q_{N}$ were calculated according to van K ooten and Snel 1990).

\section{Chlorophyll content}

L eaf disks were extracted overnight with dimethyl formamide and $\mathrm{Chl}$ content was calculated from the absorbances at 647 and $664.5 \mathrm{~nm}$ using the equations of Inskeep and Bloom (1985). The chlorophyll content of thylakoids was measured with the method of Porra et al. (1989).

\section{R esults}

\section{Senescence-associated changes in thylakoid membrane composition}

In wild-type leaves, the degradation of most thylakoid proteins on a leaf area basis occurred in parallel with the loss of $\mathrm{Chl}$. Western blots showed that the amounts of light-harvesting complexes of PSII ( $\mathrm{LHCII}$ ) and PSI $(\mathrm{LHCl})$ as well as PSII core proteins D 1, CP47 and the PSII inner antenna protein CP26 declined at roughly similar rates after 26 days after flowering (DAF) (maximum $\mathrm{Chl}$ content, Fig. 1, lane 2) and reached non-detectable levels in abscising leaves of the wild-type, which contained less than $5 \%$ of the peak $\mathrm{Chl}$ content. Since the anti-C $\mathrm{P} 26$ antibody used in this work also recognizes CP29 in some species (Falbel and Staehelin 1992) the band labelled CP26 in Fig. 1 is actually a doublet of a CP26 band and slower migrating CP 29 band. The loss of the $\beta$-subunit of the ATP synthase was less rapid than other thylakoid proteins, and abscising leaves still retained significant amounts of this protein (F ig. 1). I mmunoblots probed against cyt $f$ and the Rieske Fe-S protein of the cyt b6/f complex, and quantification of cyt $f$ in gels stained for the peroxidase activity of its heme group, show that in wild-type leaves the amounts of these proteins started to decline at 18 DAF (F ig.2) before Chl content reached its maximum at 26 DAF (data not shown).

cytG retarded the degradation of $\mathrm{Chl}$, particularly the degradation of $\mathrm{Chl} b$, during monocarpic senescence causing a decline in the $\mathrm{Chl}$ a/b ratio (data not shown). At abscission, the cytG leaves retained about $30 \%$ of their $\mathrm{Chl}$. Overall, this pattern is very similar to that observed earlier (Guiamét et al. 1991). Immunoblots confirmed earlier findings based on Coomassie-blue staining that senescing leaves of the cytG mutant retain the two main LHCII polypeptides. The cytG mutation did not cause retention of $\mathrm{LHCl}$, the $\beta$-subunit of ATP synthase or the cyt b6/f complex (F igs 1 and 2). By contrast to LHCII proteins, the PSII core proteins D 1 and
CP47 as well as PSII inner antenna proteins CP26 and CP29 disappeared faster in cytG than in wild-type (Fig. 1).

\section{Photosystem II activity and $\mathbf{F}_{\mathrm{v}} / \mathrm{F}_{\mathrm{M}}$}

PSII activity measurements confirmed the accelerated degradation of PSII reaction centre proteins in senescing leaves of the cytG mutant ( $\mathrm{Fig} .3 \mathrm{~A}$ ). Likewise, the ratio of variable to maximum fluorescence $\left(\mathrm{F}_{\mathrm{v}} / \mathrm{F}_{\mathrm{M}}\right)$ of attached leaves (Fig. 3B) remained fairly constant during senescence in the wild-type, except for a late decline of about $25 \%$, but $\mathrm{F}_{\mathrm{v}} / \mathrm{F}_{\mathrm{M}}$ decreased substantially to very low values during senescence in leaves of cytG, suggesting accelerated loss of photochemically active PSII centres.

\section{D egradation of PSII and thylakoid membrane proteins in darkness}

The accelerated degradation of PSII proteins and decline of $F_{v} / F$ M during senescence in cytG might be due to increased photodamage to PSII. Since this photodamage would not occur during senescence in darkness, the degradation of thylakoid proteins and loss of PSII activity was followed in leaves induced to senesce in continu-

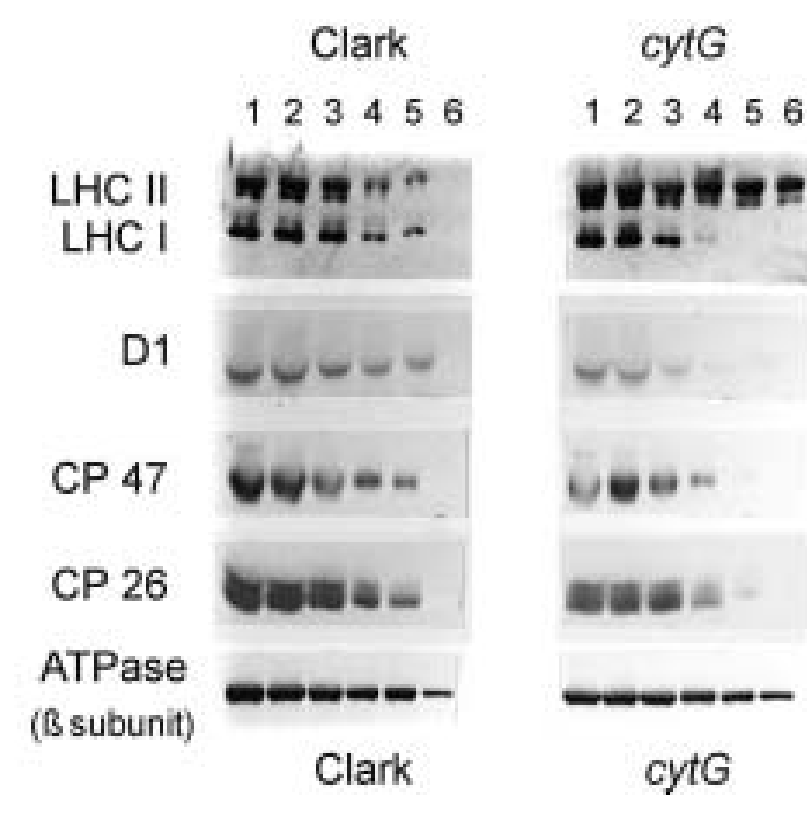

Fig. 1. I mmunoblot analysis of the changes in steady-state levels of representative thylakoid proteins during senescence. Lane 1: 18 DA F ; lane 2: 26 DA F ; lane 3: 42 DA F ; lane 4: 46 DA F ; lane 5: 52 DAF; lane 6: $58 \mathrm{DAF}$ (leaf abscission). For wild-type (cv. Clark), these stages represent: full leaf expansion (18 DAF), maximum $\mathrm{Chl}$ content (26 DAF), 25\% (42 DAF), 50\% (46 DAF) and 75\% (52 DAF) of the $\mathrm{Chl}$ degraded, and leaf abscission (58 DA F). Each lane was loaded with an amount of solubilized thylakoids equivalent to $0.05 \mathrm{~cm}^{2}$ of leaf. The anti-CP26 antibody used in this work was made against a 13-amino acid synthetic peptide, but it also recognizes CP29 in some species (F albel and Staehelin 1992). In our blots, this can be seen as a slightly diffuse doublet, the slower-migrating band corresponding to CP29 and the faster one to CP26. 
ous darkness. As with leaves undergoing monocarpic senescence in a normal photoperiod, cytG retarded the dark-induced loss of $\mathrm{Chl}$, particularly of $\mathrm{Chl} \mathrm{b}$; therefore, the $\mathrm{Chl} \mathrm{a/b}$ ratio decreased in leaves of cytG senescing in darkness (data not shown). M ost thylakoid proteins were degraded to a similar extent in wild-type and cytG leaves incubated in darkness (F ig. 4A ), with the exception of $\mathrm{LHCll}$, which was lost more slowly in cytG. The immunoblot and activity measurements of PSII in $\mathrm{Fig}$. $4 \mathrm{~B}, \mathrm{C}$ show that there was no difference in the rates of decline of PSII activity or in the loss of the $D 1$ protein between wild-type and cytG leaves senescing in darkness, indicating that the accelerated degradation of PSII reaction centre proteins in cytG leaves senescing under a normal photoperiod is light-driven.

A

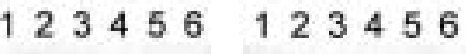
cyt f

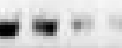

Rieske Fe-S

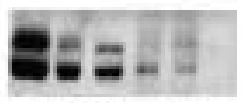

Clark

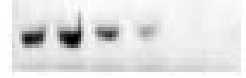

B

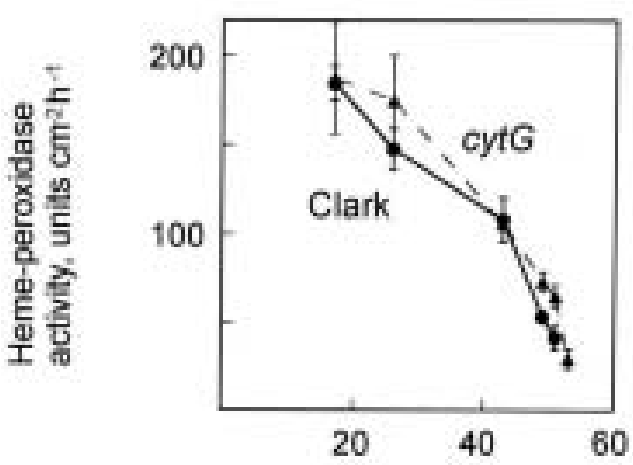

Days after flowering

Fig. 2. Changes in the levels of key proteins of the cyt b6/f complex during senescence in wild-type (cv. Clark) and cytG. Panel A immunoblot analysis of cytochrome $f$ and the R ieske $\mathrm{Fe}-\mathrm{S}$ protein of the cyt b6/f complex. Lane 1: $18 \mathrm{DAF}$; lane 2: $26 \mathrm{DAF}$; lane 3: 42 DAF; lane 4: $46 \mathrm{DAF}$; lane 5: $52 \mathrm{DAF}$; lane 6: $58 \mathrm{DAF}$ (leaf abscission). For wild-type, these stages represent: full expansion (18 DAF), maximum Chl content (26 DAF), 25\% (42 DAF), 50\% (46 $\mathrm{DAF}$ ) and $75 \%$ (52 DAF) of the $\mathrm{Chl}$ degraded, and leaf abscission (58 DAF). Each lane was loaded with an amount of solubilized thylakoids corresponding to $0.05 \mathrm{~cm}^{2}$ of leaf. Panel B - quantification of the changes in cyt $f$ by staining for its heme-peroxidase activity in mildly denaturing gels. Samples were taken when wildtype leaves reached full expansion (18DAF), maximum $\mathrm{Chl}$ content (26 DAF), 26\% (42 DAF), 60\% (48 DAF) and 81\% (52 DAF) of the $\mathrm{Chl}$ degraded. Each point is the average of three replicate measurements, and vertical bars represent standard errors (SE, standard deviation of the mean).

\section{Senescent, lincomycin-treated leaves of cytG are more susceptible to photoinhibition in vivo}

The light-accelerated loss of PSII reaction centre proteins in senescing leaves of cytG might be due to greater susceptibility to photoinhibition in the mutant. The rate of photoinhibition (i.e. light-dependent decrease of PSII activity) was measured in vivo during normal (monocarpic) senescence in wild-type cv. Clark and cytG soybeans. For the photoinhibition studies, we chose fully

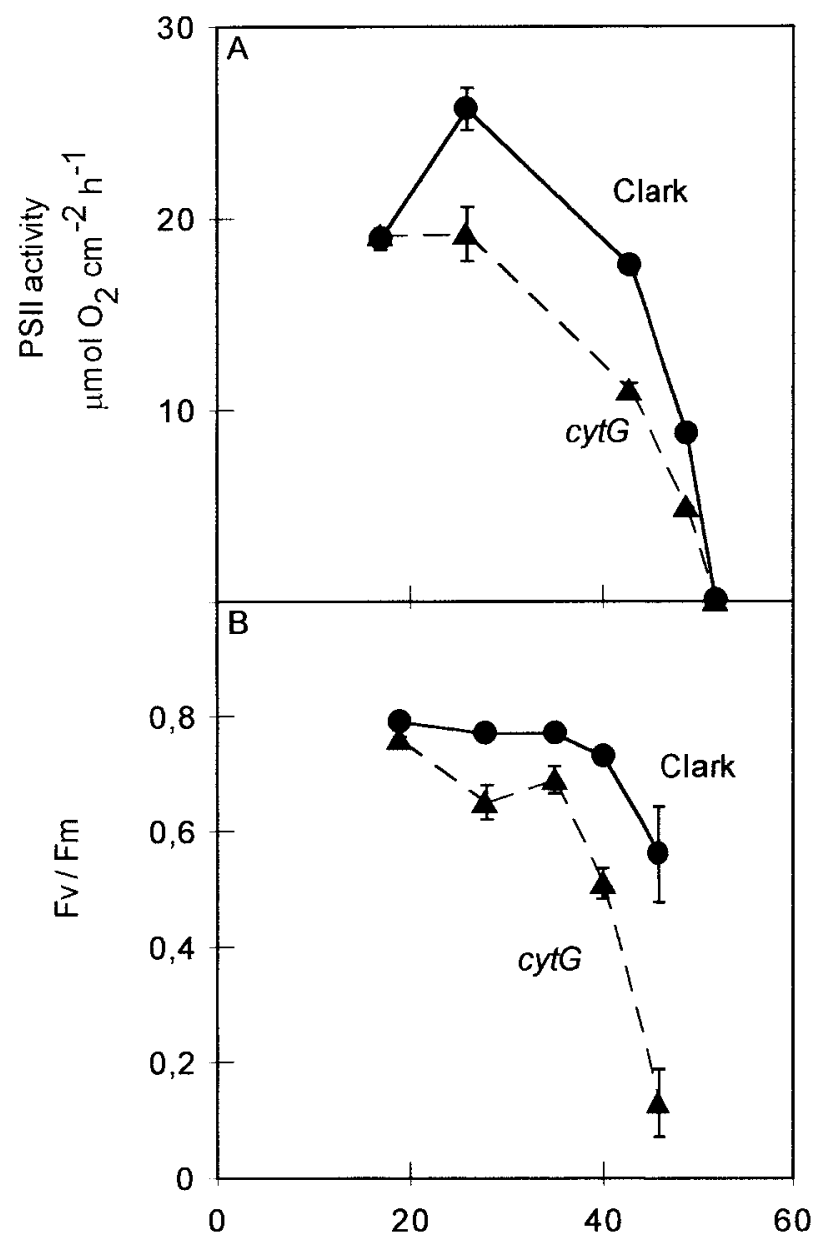

\section{Days after flowering}

Fig. 3. A - Photosystem II activity of thylakoid membranes isolated from leaves of wild-type (cv. Clark) or cytG at different stages of senescence. The samples were taken at 18, 26, 42, 48 and 52 days after flowering. For wild-type, this represents: full expansion (18 DAF), maximum $\mathrm{Chl}$ content (26 DAF), 26\% (42 DAF), 60\% (48 $\mathrm{DAF}$ ) and $81 \%$ (52 DAF) of the $\mathrm{Chl}$ degraded. Each point is the average of three replicate measurements, and vertical bars represent the standard error of the mean. B - The ratio of variable to maximum fluorescence in dark-adapted leaves of wild-type cv. Clark and cytG soybeans. For the wild-type, these stages represent maximum Chl content (19 DAF), 19\% (28 DAF), 30\% (35 DAF), 64\% (40 $\mathrm{DAF}$ ) and $92 \%$ (46 DAF) Chl loss. Each point is the average of five replicate measurements, and vertical bars represent the standard error of the mean. 
expanded mature leaves (total $\mathrm{Chl} 65.3 \pm 15.9 \mu \mathrm{g} \mathrm{cm}^{-2}$; $\mathrm{Chl} \mathrm{a/b} 3.2 \pm 0.14$ ) and senescing leaves (total $\mathrm{Chl} 40.3$ $\pm 0.68 \mu \mathrm{g} \mathrm{cm}^{-2} ; \mathrm{Chl} \mathrm{a/b} 3.3 \pm 0.10$ ) of the wild-type. The leaves were treated with lincomycin, which inhibits chloroplast protein synthesis and thus blocks the concurrent recovery of PSII from photoinhibition (A ro et al. 1993). Subsequent illumination caused a decline in PSII activity with nearly identical time-courses in mature and senescing leaves (Fig. $5 \mathrm{~A}$ ), indicating that in vivo the rate of photoinhibition does not change in wildtype leaves during the early phases of senescence. The PPF D used for the photoinhibitory illumination of the intact leaves was only slightly higher than used during growth, which ensures that the conclusions drawn from the photoinhibition experiments can be applied to the growth conditions.

While mature leaves of cytG ( total Chl $68 \pm 6.8 \mu \mathrm{g}$ $\mathrm{cm}^{-2} ; \mathrm{Chl} \mathrm{a/b} 2.7 \pm 0.13$ ) had photoinhibition rate constants similar to those of the wild-type, the rate constant of photoinhibition was 1.6 times higher in senescent (total $\mathrm{Chl} 39.0 \pm 4.2 \mu \mathrm{g} \mathrm{cm}-2$; $\mathrm{Chl}$ a/b $1.8 \pm 0.11$ ) than in mature leaves of the mutant ( $\mathrm{Fig} .5 \mathrm{~A}$ ). F urthermore, in the presence of the chloroplast protein synthesis inhibitor lincomycin, the high-light-induced degradation of the D 1 protein occurred more rapidly in senescent leaves of cytG than in the wild-type (F ig. 5C).

The higher rate of photoinhibition in intact leaves of cytG prompted us to compare in vitro photoinhibition in thylakoids isolated from untreated, senescent leaves of wild-type and the cytG mutant. Values for the in vitro rate constant of photoinhibition measured in thylakoids isolated from control and senescent leaves of both cV. Clark and cytG were similar (Table1). Because differences in the composition of the starting material might affect this comparison, we repeated the experiment with thylakoids isolated from leaves induced to senesce in the dark, so as to have equal amounts of PSII reaction centre and D 1 protein in both the wild-type and cytG thylakoids before the photoinhibition treatment. Likewise, in this experiment, thylakoids isolated from mature and senescent leaves of both the mutant and wild-type showed no difference in the rate constant of PSII inactivation under illumination in vitro (Fig. 5B).

\section{Photochemical and non-photochemical quenching in wild-type and cytG leaves}

The greater rate of photoinhibition in cytG leaves could be due to increased excitation pressure on PSII (i.e. decreased photochemical quenching, $q_{p}$ ) caused by its larger light-harvesting capacity (Park et al. 1997). Photochemical quenching $\left(q_{p}\right)$ in wild-type leaves did not change much during the early stages of senescence (up to 30\% C hl loss in wild-type cv. Clark) and declined only slightly thereafter ( $F$ ig. $6 \mathrm{~A}$ ). The changes in $q_{p}$ of cytG leaves were similar to those in the wild-type at all stages studied, and therefore, differences in $q_{p}$, i.e. in excitation pressure, do not explain the faster photoinhibition of PSII in the mutant. Since non-photochemical quenching $\left(q_{N}\right)$ has been claimed to protect PSII against photoinhibition (Park et al. 1997), another possible explanation for the enhanced photoinhibition-susceptibility of cytG may be that inefficient non-photochemical quenching of excitation energy renders senescing cytG leaves more sensitive to photodamage. However, in wild-type leaves, $q_{N}$ declined markedly during senescence ( $F$ ig. 6B), but in cytG, $q_{N}$ remained relatively constant, and therefore senescing leaves of the mutant maintained a higher $\mathrm{q}_{\mathrm{N}}$ than the wildtype. Thus, non-photochemical quenching afforded cytG leaves a larger capacity than the wild-type to dissipate excitation energy absorbed by the light-harvesting pigments. We do not know whether the sustained capacity for

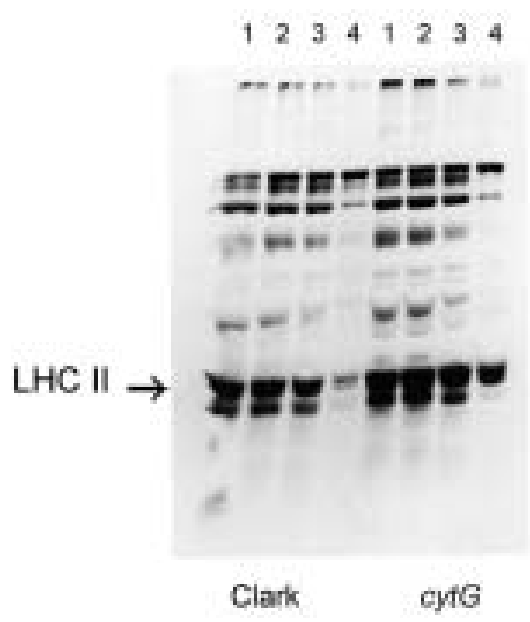

D1

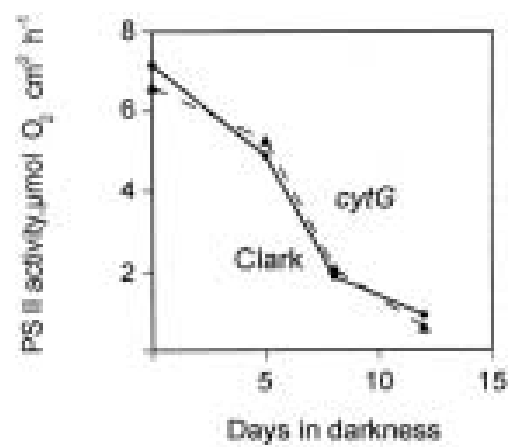

12341234

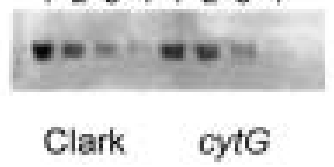

Fig. 4. A - Electrophoretic analysis (SD SPAGE) of thylakoid proteins (equivalent to $0.25 \mathrm{~cm}^{2}$ of leaf per lane) stained with Coomassie Blue, B - photosystem II activity of isolated thylakoid membranes and C - immunoblot of thylakoid proteins (each lane was loaded with an amount of solubilized thylakoids equivalent to $0.05 \mathrm{~cm}^{2}$ of leaf) probed with an anti-D 1 antibody. Wild-type cv. Clark and cytG leaves were incubated in continuous darkness for 12 days, lane 1 : day 0; lane 2: day 5; lane 3: day 8; lane 4: day 12 . In panel $B$, each point is the average of three replicate measurements; The se bars were smaller than the symbols. 

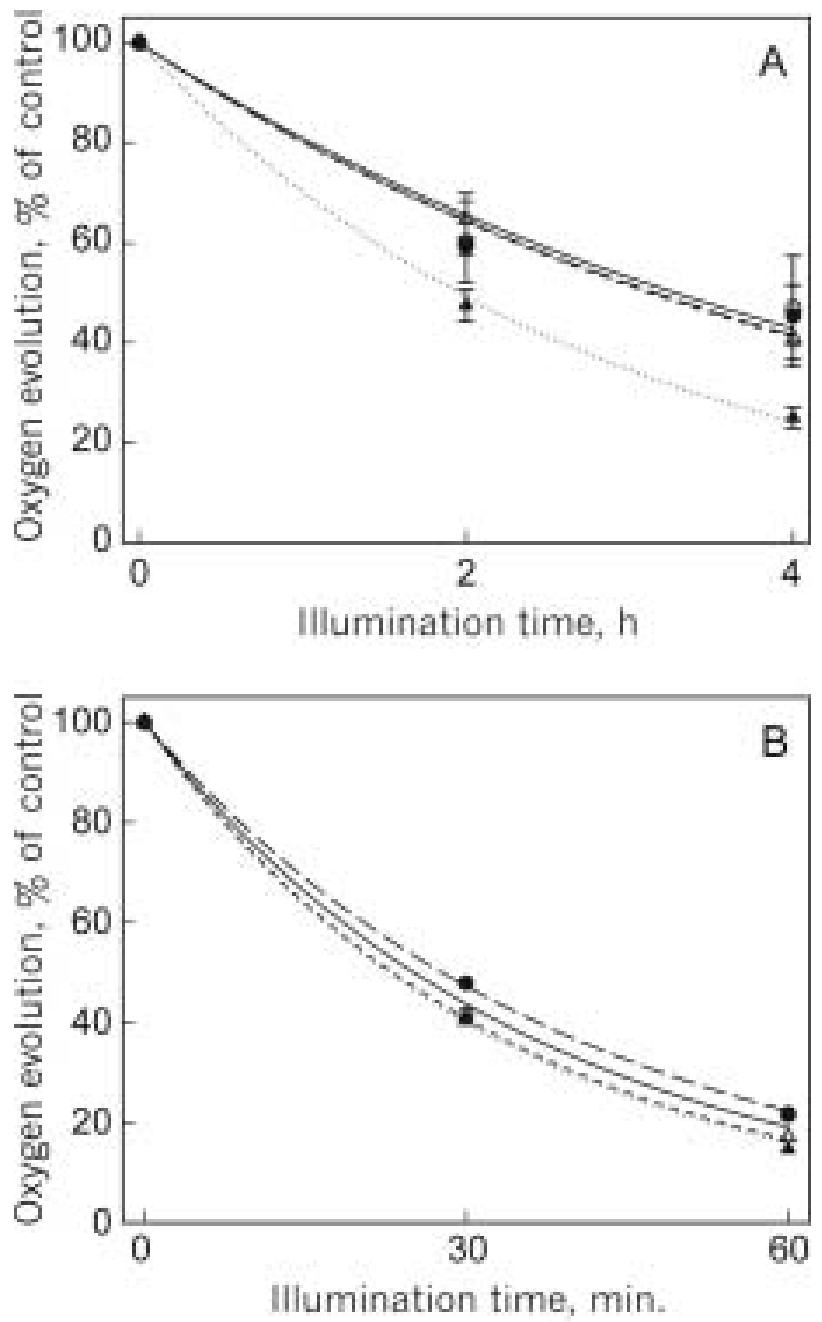

C

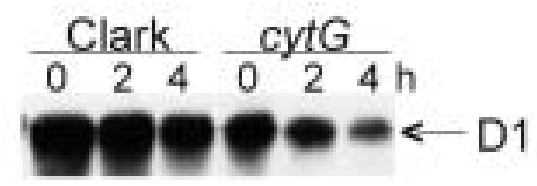

$q_{N}$ quenching in cytG is caused by retention of leaf xanthophylls, by a better capacity to maintain the transthylakoid pH gradient during senescence in the mutant, or by some other factor.

\section{Synthesis of the D 1 protein of PSII in senescing leaves of cytG}

The D 1 protein of the PSII reaction centre was degraded quite rapidly during photoinhibition of PSII activity (Fig. 5B), and indeed D 1 protein levels appeared to decline faster than those of other PSII proteins, e.g. CP26
Fig. 5. A - Photoinhibition of lincomycin-treated leaves of wildtype cv. Clark (circles) and cytG (triangles) soybeans. M ature (open symbols) and senescent (solid symbols) leaves were irradiated at the PPFD of $560 \mu \mathrm{mol} \mathrm{m} \mathrm{m}^{-2} \mathrm{~s}^{-1}$, and light-saturated oxygen evolution activity was measured in thylakoids isolated from treated leaves. Each data point represents an average of three independent experiments. The control oxygen evolution activities were 377, 327, 368 and $207 \mu \mathrm{mol} \mathrm{O} \mathrm{mg}^{-1} \mathrm{Chl} \mathrm{h}^{-1}$ in mature Clark, senescent Clark, mature cytG and senescent cytG, respectively. B - In vitro photoinhibition of thylakoids isolated from leaves of cv. Clark (circles) and cytG (triangles). Thylakoids isolated from mature (open symbols) and senescent (solid symbols) leaves were illuminated at the PPF D of $1000 \mu \mathrm{mol} \mathrm{m} \mathrm{m}^{-2} \mathrm{~s}^{-1}$ at $20^{\circ} \mathrm{C}$, and light-saturated oxygen evolution activity was measured from aliquots taken at regular intervals. The control oxygen evolution activities were 283, 204, 100 and $74 \mu \mathrm{mol}$ $\mathrm{O}_{2} \mathrm{mg}^{-1} \mathrm{Chl} \mathrm{h}^{-1}$ in mature Clark, senescent Clark, mature cytG and senescent cytG, respectively. The curves in A and B show the best fit to a first-order equation and the vertical bars represent SE. $\mathrm{C}$ - Western blot showing the decrease in the D 1 protein content in senescent leaves of wild-type cv. Clark and cytG subjected to a similar photoinhibitory treatment as in A. The same amount of chlorophyll was loaded in each well.

and CP47, in senescing leaves of cytG (Fig. 1). To exclude the possibility that the rapid loss of the $D 1$ protein is caused by a reduced capacity for de novo protein synthesis, we measured the changes in translation activity of $D 1$ protein and the steady-state levels of the psbA mRNA during senescence (Fig. 7). The results showed that the $D 1$ protein was actively translated in senescent leaves of both wild-type and cytG (Fig. 7A). For reasons explained elsewhere (Noodén et al. 1997), we believe normalization on the basis of FW (Fig. 7D) better reflects the concentration of mR N As in senescing tissues, and this decreases in senescing leaves. The amounts of psbA mR NA were similar in both genotypes during senescence (Fig. 7B,C,D); however, the concentrations of psbA expressed on the basis of $F \mathrm{~W}$ were slightly higher in cytG (Fig. 7D).

\section{D iscussion}

\section{$B$ reakdown of thylakoid proteins during senescence:} alterations caused by the 'stay-green' mutation cytG

In wild-type genotypes of higher plants, the breakdown of the thylakoid membranes starts with the degradation of the cyt b6/f complex, and that is followed by the roughly simultaneous loss of $\mathrm{Chl}$ and decline of the pro-

Table1. Photoinhibition rate constants $\left(\mathrm{h}^{-1}\right)$ of thylakoids isolated from non-treated leaves and subjected to photoinhibitory illumination (PPFD $1000 \mu \mathrm{mol} \mathrm{m} \mathrm{m}^{-2} \mathrm{~s}^{-1}$ ) at $20^{\circ} \mathrm{C}$. Oxygen evolution activity was measured periodically during the illumination and the rate constants were calculated from first-order fits of the decrease of the activity. Wild-type and cytG thylakoids were isolated from leaves harvested at different stages of senescence. For the wild-type cv. Clark, these stages represent: maximum $\mathrm{Chl}$ content (20 DAF), 38 (45 DA F) and 70\% Chl loss (55 DA F ). F igures in parenthesis represent standard errors.

\begin{tabular}{llc}
\hline DAF & Clark & CytG \\
\hline 20 & $1.8(0.1)$ & $2.1(0.3)$ \\
45 & $2.0(0.02)$ & $1.9(0.02)$ \\
55 & $1.7(0.07)$ & $1.8(0.2)$ \\
\hline
\end{tabular}




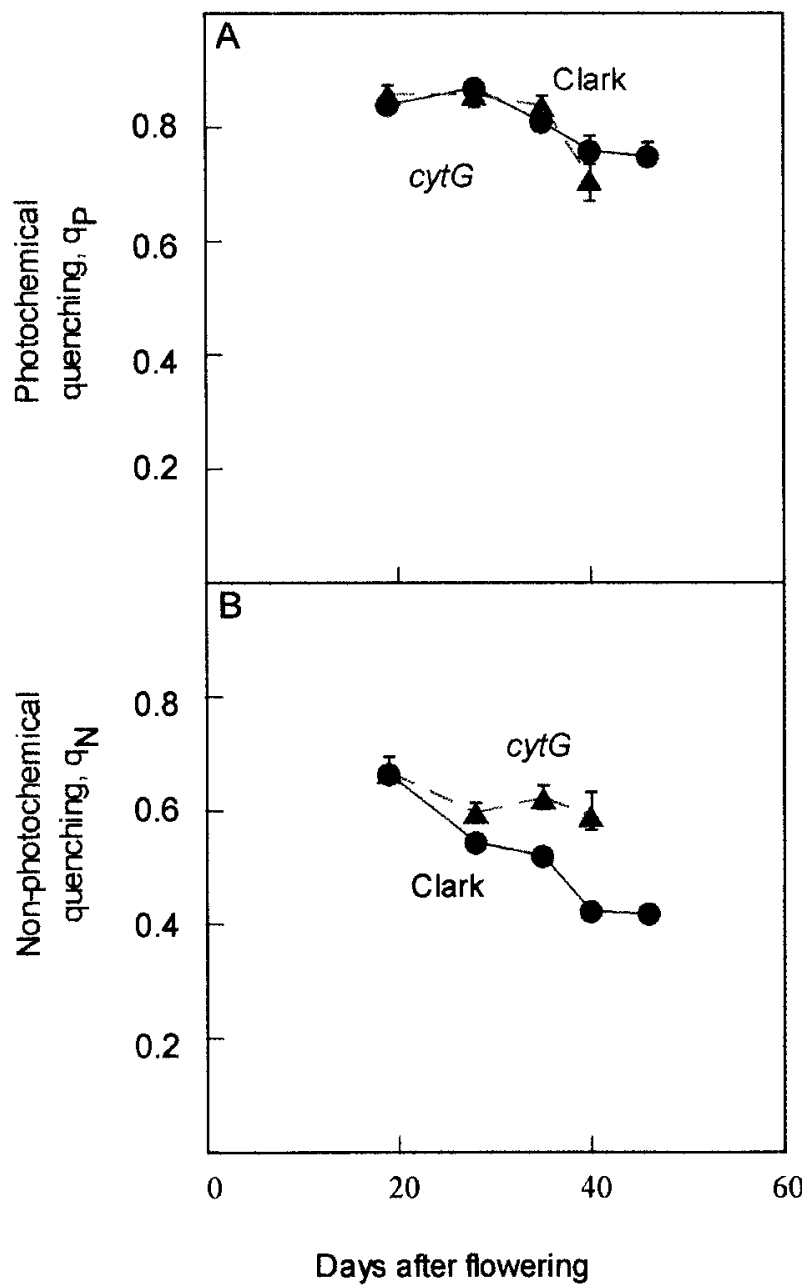

Fig.6. Photochemical (A) and non-photochemical quenching (B) of $\mathrm{Chl}$ a fluorescence in leaves of wild-type cv. Clark and cytG soybeans at different stages during senescence. $M$ easurements were made at 19, 28, 35, 40 and 46 DAF. For the wild-type, these stages represent maximum $\mathrm{Chl}$ content (19 DAF), 19\% (28 DAF), 30\% (35 DA F ), 64\% (40 DA F ) and 92\% (46 DA F ) Chl loss. The fluorescence kinetics in cytG at $46 \mathrm{DAF}$ precluded the accurate determination of $\mathrm{q}_{\mathrm{p}}$ and $\mathrm{q}_{\mathrm{N}}$ and therefore $\mathrm{q}_{\mathrm{p}}$ and $\mathrm{q}_{\mathrm{N}}$ for cytG at $46 \mathrm{DAF}$ are not shown. Vertical bars represent the standard error of the mean.

tein components of both photosystems. Interestingly, the ATP synthase is broken down more slowly and persists at low levels even into very late senescence (Ben-D avid et al. 1983, H olloway et al. 1983, R oberts et al. 1987).

Since $\mathrm{Chl}$ degradation during senescence is partially inhibited in cytG, mutant leaves are shed pale green, and other green organs that normally yellow during senescence (e.g. stems, pod walls and seed cotyledons) also remain pale green when the plants die at seed maturity (G uiamét et al. 1990). The main effect of cytG on Chl levels is due to the inhibition of $\mathrm{Chl} b$ degradation ( $\mathrm{G}$ uiamét et al. 1991), which correlates with substantial preservation of $\mathrm{LHCll}$, the main $\mathrm{Chl}$ a/b light-harvesting complex associated with PSII (Fig.1, Guiamét et al. 1991). By contrast, the breakdown of other $\mathrm{Chl}$ a/bbinding proteins like $\mathrm{LHCl}, \mathrm{CP} 29$ and CP 26 , and of the other photosynthetic membrane protein complexes PSI, AT Pase and cyt b6/f occurs normally in cytG (Figs 1 and 2). In some 'stay-green' mutants of higher plants (e.g. sid $^{G}$. of F estuca and the $\mathrm{NI} 16$ line of pea), $\mathrm{Chl}$ retention seems to be due to a deficiency in pheophorbide dioxygenase activity, the enzyme catalysing the third step in the $\mathrm{Chl}$ degradation pathway (M atile et al. 1996, Thomas et al. 1996). However, cytG does not seem to act through that mechanism. First, $\mathrm{Chl}$ a, some $\mathrm{Chl}$ a/b binding proteins (e.g. $\mathrm{LHCl}$ ) and even $\mathrm{Chl} b$ albeit with a delay, are degraded normally in cytG. Second, cytG is a maternally inherited mutation, whereas sid ${ }^{G}$ and $N 16$ are nuclear mutations. The specific inhibition of $\mathrm{L} \mathrm{HCll}$ loss in cytG suggests that $\mathrm{LHCI}$ is degraded through a pathway different from that involved in the breakdown of other thylakoid proteins.

\section{Susceptibility to photoinhibition during senescence}

Susceptibility to (i.e. rate of) photoinhibition has been reported to increase during senescence in some species ( $K$ ar et al. 1993, M urchie et al. 1999). H owever, under constant environmental conditions, mature and senescent leaves as well as isolated thylakoids of wild-type soybeans are equally susceptible to photoinhibition of PSII, indicating that senescence per se does not affect the susceptibility to photodamage. Some earlier observations may actually reflect senescence-associated changes in leaf orientation that alter the amount of light absorbed by leaves of different ages ( $M$ urchie et al. 1999). It is also possible that the capacity to repair photodamage is lowered in senescent leaves ( $\mathrm{K}$ ar et al. 1993). However, the results of the present study show that the capacity to synthesize the $D 1$ protein is retained at least until mid senescence (Fig. 7). Likewise, translation of $D 1$ remains active in senescing leaves of bean even in spite of decreasing levels of the corresponding psbA mR NA (D roillard et al. 1992).

\section{Photoinhibition and loss of photosystem II core polypeptides in cytG}

The cytG mutation exerts opposite effects on $\mathrm{LHCII}$ and the $\mathrm{PSI}$ I reaction centre. While $\mathrm{LHClI}$ is retained in the mutant, the PSII reaction centre is degraded faster than in wild-type leaves. The accelerated degradation of the PSII core proteins (Fig. 1) and the enhanced loss of PSII oxygen evolution activity in cytG (Fig. $3 \mathrm{~A}$ ) are linked to photodamage of PSII, as these phenomena cannot be seen if senescence is induced in darkness (Fig. 4). The more rapid loss of the $D 1$ protein compared to other PSII-core proteins in cytG suggests that the light-induced enhancement of PSII loss is related to photoinhibition of PSII. In fact, senescing leaves of cytG are more susceptible to photoinhibition than either senescing leaves of the wild-type or mature leaves of the mutant. Interestingly, thylakoids isolated from senescing leaves of cytG do not show any increase in the rate of photoinhibition. Fluorescence induction measurements in the 
presence of $D C M U$ indicate that the antenna size of PSII increases in senescing thylakoids of cytG (data not shown). Thus, the fact that cytG thylakoids are not more susceptible to photoinhibition confirms that the antenna size of PSII plays no significant role in susceptibility to photoinhibition (Tyystjärvi et al. 1992, 1994). Likewise, the photochemical capacity of PSII ( $\left.F_{v} / F_{M}\right)$ declines at similar rates during senescence of wild-type and the sid ${ }^{G}$ Festuca mutant, in spite of retention of $\mathrm{LHCll}$ in sid ${ }^{\mathrm{G}}$ (K ingston-Smith et al. 1997), which lends support to our conclusion that retention of $\mathrm{LHClI}$ alone is not the reason for faster photoinhibition in cytG.

\section{Fluorescence quenching in cytG}

Several mechanisms dissipate energy absorbed in excess of that needed for $\mathrm{CO}_{2}$ fixation ( $\mathrm{H}$ orton et al. 1996), presumably helping to prevent the formation of active oxygen species that could impair photosystem function (Foyer et al. 1994). Photochemical and non-photochemical quenching phenomena have been shown to affect the balance between photoinhibitory damage and repair of PSII in several species (Park et al. 1997).

Photochemical quenching may decrease during senescence (Šesták and Šiffel 1997), but in leaves of wildtype soybeans $q_{p}$ remained relatively constant until quite late in senescence. Photochemical quenching in cytG was similar to the wild-type at all stages of senescence. $\mathrm{N}$ onphotochemical quenching may increase (Šesták and Šiffel 1997, M urchie et al. 1999) or decline (Fig.6B) in senescing leaves, probably depending on environmental conditions. Interestingly, while non-photochemical quenching declined during senescence of wild-type leaves, $q_{N}$ remained constant in senescing leaves of the cytG mutant. The higher $\mathrm{q}_{\mathrm{N}}$ of senescing cytG leaves may have helped to maintain a high $q_{p}$ in spite of an increasing antenna size of PSII (data not shown). In any event, senescing cytG leaves appeared to dissipate absorbed energy more efficiently than the wild-type cV. Clark, reinforcing the conclusion that the light-accelerated loss of PSII in cytG is not caused by absorption of excess energy by the retained L HCII.

\section{R epair of photosystem II in cytG}

Photoinhibition occurs at low photon yield in illuminated leaves such as those used here (Tyystjärvi and A ro 1996). The resulting photodamage to the PSII reaction centre is repaired by degradation of the damaged D 1 protein and re-synthesis of a new copy of D 1 (A ro et al. 1993, O kada et al. 1996). Since we measured photoinhibition in the presence of the translation inhibitor lincomycin, the enhanced rate of photoinhibition in senescing leaves of cytG is not primarily due to inefficient repair of damaged PSII centres.

However, since PSII core proteins and many chloroplast ribosomal proteins are chloroplast-encoded, and cytG is a maternally inherited mutation, we tested whether the cytG mutation has an additional deleterious effect on chloroplast protein synthesis and therefore on the PSII repair cycle. The levels of the psbA mR NA in cytG soybeans were equal to or greater than those in the wild-type (Fig. 7B,C,D) suggesting that the accelerated loss of the D 1 protein in cytG is not due to decreased
A
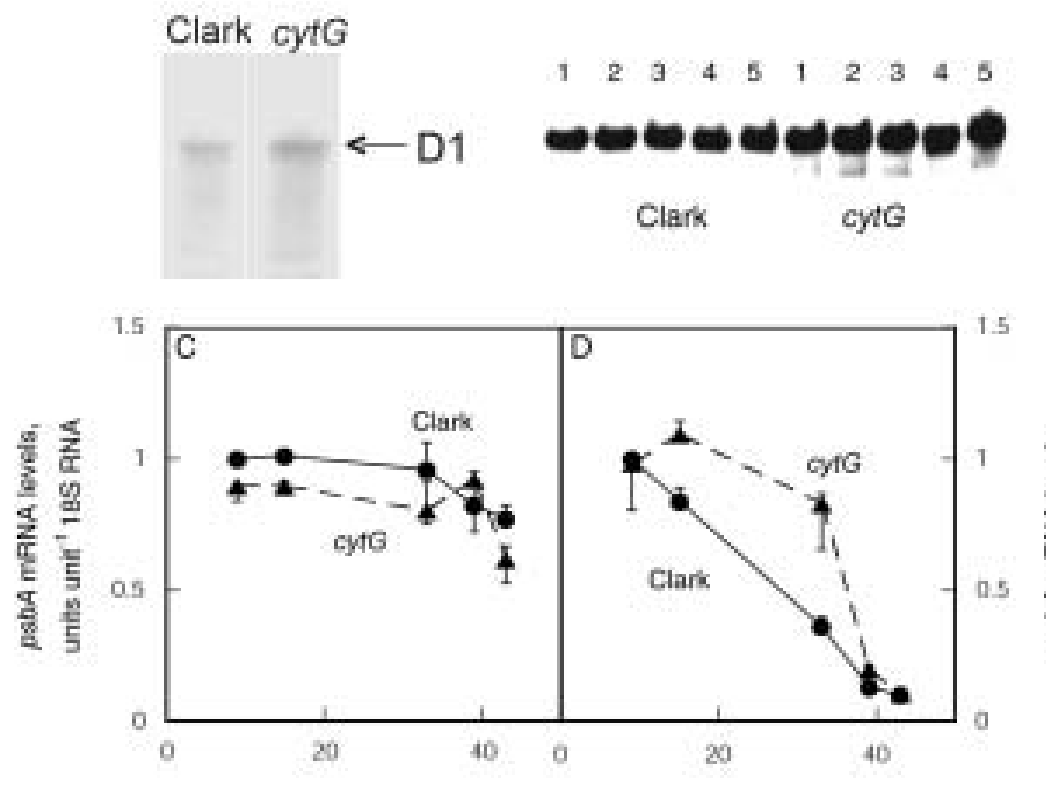

Days after flowering

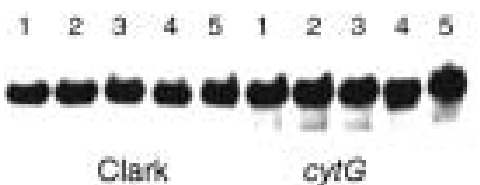

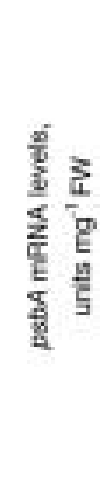


transcription of the psbA gene. M oreover, D 1 is synthesized at a similar rate by senescing leaves of wild-type and cytG soybeans (Fig. 7A). Thus, the accelerated loss of PSII in cytG is due to a higher rate of photodamage, rather than to decreased synthesis of the $\mathrm{D} 1$ protein.

In conclusion, susceptibility to photoinhibition does not change during senescence of wild-type soybean leaves. H owever, photoinhibition in senescing leaves is increased by the cytG mutation, even though fluorescence-quenching mechanisms are quite active in the mutant. This enhanced photodamage accelerates degradation of the D 1 protein, which in turn may enhance the break down of other PSII polypeptides in the mutant. Since the rate of photoinhibition is not altered in isolated thylakoids of cytG, a stromal or cytosolic factor, rather than absorption of excess light by the retained L HCII, appears to be responsible for the faster photoinhibition in cytG. The nature of this factor remains to be elucidated, but it may be possible that the same factor conferring enhanced susceptibility to photoinhibition is responsible for the retention of $\mathrm{LHCII}$ in cytG.

A cknowledgements - We thank Drs S. Gepstein, B. R. Green, M. K inkema, A. M attoo, R. M cC arthy, J. M ullet, R. Sayre, B. Sears and $A$. Staehelin for the gift of antibodies and clones used in this work. We thank DrC. F. Yocum for the use of his $\mathrm{O}_{2}$ electrode and $\mathrm{Dr}$ J. Flore for the OS-500 Chlorophyll Fluorescence M eter. This work was financed partially by a Biotechnology Career F ellowship from The R ockefeller Foundation to J.J.G, and by F undacion A ntorchas (A rgentina). J. J. G. is a researcher at C. I. C., Pcia de Buenos A ires, A rgentina. E. T., T. T and M. K. were supported by a fellowship from A cademy of $F$ inland.

\section{R eferences}

A fitlhile M, D ent R, Cowan A (1993) Changes in carotenoid composition in senescing leaves of $\mathrm{H}$ ordeum vulgare L. CV. Dyan. J Plant Physiol 142: 43-49

A ro E-M , Virgin I, A ndersson B (1993) Photoinhibition of photosynthesis: inactivation, protein damage and turnover. Biochim Biophys A cta 1143: 113-134

Bachmann A, F ernandez-L opez J, G insburg S, Thomas H, Bouwkamp J C, Solomos T, M atile P (1994) Stay-green genotypes of P haseolus vulgaris L. chloroplast proteins and chlorophyll catabolites during foliar senescence. N ew Phytol 126: 593-600

Ben-D avid H, N elson N, G epstein S (1983) D ifferential changes in the amount of protein complexes in the chloroplast membrane during senescence of oat and bean leaves. Plant Physiol 73: 507510

Bernard RTL, Weiss M G (1973) Qualitative genetics. In: Caldwell BE ed Soybeans: Improvement, Production and U ses. A m Soc of A gronomy, M adison, WI, pp 117-154

Camm EL, Green BR (1980) Fractionation of thylakoid membranes with the nonionic detergent octyl-b-D-glucopyranoside Resolution of chlorophyll-protein complex II into two chlorophyll-protein complexes. Plant Physiol 66: 428-432

Camm EL, G reen BR (1989) The chlorophyll ab complex, CP29, is isolated with the photosystem II reaction centre core. Biochim Biophys A cta 974: 180-184

Canfield M R, Guiamét JJ, Noodén LD (1995) A Iteration of soybean seedling development in darkness and light by the staygreen mutation cytG and $\mathrm{Gd}_{1} \mathrm{~d}_{2}$. A nn Bot 75: 143-150

Chao WS, Liu V, Thomson WW, Platt K, Walling LL (1995) The impact of chlorophyll-retention mutations, $d_{1} d_{2}$ and cyt-G 1 , during embryogeny in soybean. Plant Physiol 107: 253-262

D roillard M J, Bate N J, R othstein SJ, Thompson JE (1992) A ctive translation of the D-1 protein of photosystem II in senescing leaves. Plant Physiol 99: 589-594
Falbel TG, Staehelin A (1992) Species-related differences in the electrophoretic behavior of CP 29 and CP 26: an immunochemical analysis. Photosynth Res 34: 249-262

Foyer C, Lelandais M, K unert KJ (1994) Photooxidative stress in plants. Physiol Plant 92: 696-717

Gepstein S (1988) Photosynthesis. In: Noodén LD, Leopold AC (eds) Senescence and A ging in Plants. A cademic Press, San Diego, CA, pp 85-109

Guiamét JJ, G iannibelli M C (1996) N uclear and cytoplasmic 'stay green' mutations of soybean alter the loss of leaf soluble proteins during senescence. Physiol Plant 96: 655-661

Guiamét JJ, Schwartz E, Pichersky E, N oodén LD (1991) Characterization of cytoplasmic and nuclear mutations affecting chlorophyll and chlorophyll-binding proteins during senescence in soybean. Plant Physiol 96: 227-231

Guiamét JJ, Teeri JA, N oodén LD (1990) Effects of nuclear and cytoplasmic genes altering chlorophyll loss on gas exchange during monocarpic senescence in soybean. Plant Cell Physiol 31: 1123-1130

H olloway PJ, M aclean DJ, Scott KJ (1983) R ate-limiting steps of electron transport in chloroplasts during ontogeny and senescence of barley. Plant Physiol 72: 795-801

Horton P, R uvan AV, Walters RG (1996) Regulation of light harvesting in green plants. A nnu Rev Plant Physiol Plant M ol Biol 47: 655-684

Inskeep W, Bloom PR (1985) Extinction coefficients of chlorophyll $\mathrm{a}$ and $\mathrm{b}$ in $\mathrm{N}, \mathrm{N}$-dimethylformamide and $80 \%$ acetone. Plant Physiol 77: 483-485

J ohn I, D rake R, Farrell A, Cooper W, Lee P, H orton P, G rierson D (1995) D elayed leaf senescence in ethylene-deficient ACC-oxidase antisense tomato plants: molecular and physiological analysis. Plant J 7: 483-490

K ar M, Streb P, H ertwig B, F eierabend J (1993) Sensitivity to photodamage increases during senescence in excised leaves. J Plant Physiol 141: 538-544

K im S, Pichersky E, Yocum CF (1994) Topological studies of spinach $22 \mathrm{kD}$ a protein of photosystem II. Biochim Biophys A cta 1188: $339-348$

K ingston-Smith A H, Thomas H, Foyer CH (1997) Chlorophyll a fluorescence and antioxidant analyses provide evidence for the operation of alternative electron sinks during leaf senescence in a stay-green mutant of F estuca pratensis. Plant C ell Environ 20: 1323-1337

Laemmli UK (1970) Cleavage of structural proteins during assembly of the head of bacteriophage T4. N ature 227: 680-685

$M$ atile $\mathrm{P}, \mathrm{H}$ ortensteiner S, Thomas H, K rautler B (1996) Chlorophyll breakdown in senescent leaves. Plant Physiol 112: 14031409

M urchie EH, Chen Y-S, H ubbart S, Peng S, H orton P (1999) Interactions between senescence and leaf orientation determine in situ patterns of photosynthesis and photinhibition in fieldgrown rice. Plant Physiol 119: 553-563

N oodén LD (1988) The phenomena of senescence and aging. In: $N$ oodén LD, L eopold AC (eds) Senescence and A ging in Plants. A cademic Press, San Diego, CA, pp 1-50

N oodén LD, G uiamét JJ (1996) G enetic control of senescence and aging in plants. In: Schneider EL, R owe JW (eds) $\mathrm{H}$ andbook of the Biology of A ging, 4th edn. A cademic Press, San D iego, CA, pp 94-118

N oodén LD, G uiamét J], John I (1997) Senescence mechanisms. Physiol Plant 101: 746-753

Okada K, I keuchi M, Yamamoto N, Ono T-A, M iyao M (1996) Selective and specific cleavage of the D 1 and D 2 proteins of Photosystem II by exposure to singlet oxygen: F actors responsible for the susceptibility to cleavage of the proteins. Biochim Biophys A cta 1274: 73-79

Park Y-I, Chow WS, A nderson J M (1997) A ntenna size dependency of photoinactivation of photosystem II in light-acclimated pea leaves. Plant Physiol 115: 151-157

Pätsikkä E, A ro E-M , Tyystjärvi E (1998) Increase in the quantum yield of photoinhibition contributes to copper toxicity in vivo. Plant Physiol 117: 619-627

Porra RJ, Thompson WA, K riedemann PE (1989) Determination of accurate extinction coefficients and simultaneous equations for assaying chlorophyll $a$ and $b$ with four different solvents: verification of the concentration of chlorophyll by atomic absorption spectroscopy. BBA 975: 384-394 
Roberts DR, Thompson JE, Dumbroff EB, Gepstein S, M attoo A K (1987) D ifferential changes in the synthesis and steady-state levels of thylakoid proteins during bean leaf senescence. Plant M ol Biol 9: 343-353

Sambrook J, Fritsch EF, M aniatis T (1989) M olecular Cloning: a Laboratory $\mathrm{M}$ anual, 2 nd edn. Cold Spring $\mathrm{H}$ arbor Laboratory Press, Cold Spring H arbor, N ew York, NY

Šesták Z, Šiffel P (1997) L eaf-age related differences in chlorophyll fluorescence. Photosynthetica 33: 347-369

Thomas PE, Ryan D, Levin W (1976) An improved staining procedure for the detection of the peroxidase activity of cytochrome P-450 on sodium dodecyl sulfate polyacrylamide gels. A nal Biochem 75: 176

Thomas H, Schellenberg M, Vicentini F, M atile P (1996) G regor $M$ endel's green and yellow pea seeds. Bot A cta 109: 3-4

Thomas H , Smart CM (1993) Crops that stay green. A nn A ppl Biol 123: 193-219
Tyystjärvi E, A li-Y rkkö K, K ettunen R, A ro E-M (1992) Slow degradation of the $D 1$ protein is related to the susceptibility of low-light grown pumpkin plants to photoinhibition. Plant Physiol 100: 1310-1317

Tyystjärvi E, A ro E-M (1996) The rate constant of photoinhibition, measured in lincomycin-treated leaves, is directly proportional to light intensity. Proc N atl A cad Sci U SA 93: 2213-2218

Tyystjärvi E, K ettunen R, A ro E-M (1994) The rate constant of photoinhibition in vitro is independent of the antenna size of photosystem II but depends on temperature. Biochim Biophys A cta 1186: 177-185

van Kooten OF, Snel JFH (1990) The use of chlorophyll fluorescence nomenclature in plant stress physiology. Photosynth Res 25: $147-150$ 